\title{
SŁOWO OD REDAKCJI
}

Kilka lat doświadczeń redagowania czasopisma skłoniło nas do wniosku, że łamów „Meluzyny" nie możemy oddawać wyłącznie młodym badaczom. Chcemy, podkreślamy to z przekonaniem, by „Meluzyna” stwarzała okazję do spotkań przedstawicielom nauki reprezentującym różne ośrodki, kształtowanych w wielu środowiskach, adeptom wiedzy wyrastającym w odmiennych szkołach naukowych, rozwijających się pod opieką własnych mistrzów.

Podobnie jak miało to miejsce do tej pory na wszystkich naszych konferencjach (Pobierowo 2017, Wisła 2018, Pobierowo 2019 i konferencja online w roku 2020), do publikacji na łamach „Meluzyny” zapraszać będziemy również badaczy wszystkich pokoleń, by czasopismo dawało okazję do spotkań i dyskusji między uczniami a mistrzami. W tej zmodyfikowanej formule chcemy budować zeszyty naszego pisma począwszy od rocznika 2020. W tym zeszycie prezentujemy tekst prof. Jakuba Z. Lichańskiego, obecnego od lat na łamach naszego pisma jako recenzent naszych młodszych kolegów i koleżanek.

Maria Barłowska, Ewa Cybulska-Bohuszewicz,

Dariusz Dybek, Michat Kuran, Witold Wojtowicz we wrześniu 2020 roku 


\section{FROM THE EDITOR}

A few years of the editorial experience have led us to conclusion that "Melusine" cannot be dedicated solely to young researchers. We hope that the journal would create an opportunity to bring representatives of various fields together: people educated in different institutions and scholars from many different schools and developed under their masters.

Following the example of all our conferences until now (Pobierowo in 2017, Wisła in 2018, Pobierowo in 2019 and online conference in 2020), we will be inviting a wide range of scholars from all generations to publish in "Melusine" so that the journal could bring the students and their masters together. We will start publishing in this new formula from the beginning of 2020. In this issue are we presenting the text of Prof. Jakub Z. Lichański, who has been part of our journal for years as a reviewer for our younger colleagues.

Maria Barłowska, Ewa Cybulska-Bohuszewicz, Dariusz Dybek, Michat Kuran,

Witold Wojtowicz

September 2020 